\title{
BIOMASS EQUATIONS FOR CAATINGA SPECIES
}

\author{
Mayara DALLA LANA ${ }^{*}$, Rinaldo Luiz Caraciolo FERREIRA², José Antônio Aleixo da SILVA², \\ Gustavo Pereira DUDA ${ }^{2}$, Carlos Frederico Lins e Silva BRANDÃO ${ }^{3}$, \\ Anderson Francisco da SILVA ${ }^{2}$
}

\author{
${ }^{1}$ Instituto Federal de Educação, Ciência e Tecnologia de Pernambuco, Garanhuns, Pernambuco, Brasil. \\ ${ }^{2}$ Depto. de Ciência Florestal, Universidade Federal Rural de Pernambuco, Recife, Pernambuco, Brasil. \\ ${ }^{3}$ Centro de Ciências Agrárias, Universidade Federal de Alagoas, Rio Largo, Alagoas, Brasil. \\ *E-mail: mayara.dallalana@garanhuns.ifpe.edu.br
}

\begin{abstract}
The objective of this work was to determine the proportions of stem, branches and leaves in relation to total dry aboveground biomass and adjust statistical models to estimate the biomass of the main species in an area of Caatinga. The number of trees cut and with the determined total aboveground biomass was 15 for Anadenanthera colubrina, Aspidosperma pyrifolium, Cnidoscolus quercifolius, Mimosa ophthalmocentra, Mimosa tenuiflora, and Poincianella bracteosa, and 30 for Bauhinia cheilantha and Croton heliotropiifolius. The data of total dry aboveground biomass were used as dependent variables and the diameter at breast height and total height of individuals per species were used as the independent variables for adjusting the models. Eight models were tested for each species and for all grouped species. Traditional statistical criteria was used for selecting the best equation. The proportions of the species were quantified for both their biomass compartments and for the total biomass, showing great variation between species and individuals of the same species. Dry aboveground biomass equations were developed with good precision statistics and can therefore be used for estimating biomass in Caatinga regions.
\end{abstract}

Keywords: Regression analysis, diameter at breast height, total height.

\section{EQUAÇÕES DE BIOMASSA PARA ESPÉCIES DA CAATINGA}

RESUMO: O objetivo deste trabalho foi determinar as proporções de fuste, galhos e folhas em relação a biomassa total seca acima do solo e ajustar modelos estatísticos para estimativa da biomassa das principais espécies arbustivo-arbóreas em uma área de Caatinga. O número de indivíduos abatidos e com a biomassa aérea total determinada foi de 15 para Anadenanthera colubrina, Aspidosperma pyrifolium, Cnidoscolus quercifolius, Mimosa ophthalmocentra, Mimosa tenuiflora, Poincianella bracteosa e, de 30 para Bauhinia cheilantha e Croton heliotropiifolius. Para ajuste dos modelos foram utilizados os dados de biomassa total seca acima do solo coletados como variável dependente e as variáveis independentes foram o diâmetro à altura do peito e a altura total dos indivíduos por espécie. Foram testados oito modelos para cada uma das espécies e para todas as espécies agrupadas. Para a seleção da melhor equação utilizou-se os tradicionais critérios estatísticos. As proporções de biomassa das espécies foram quantificadas, tanto para os seus compartimentos, quanto para o total e apresentaram uma grande variação entre espécies e indivíduos da mesma espécie. Equações de biomassa aérea seca foram ajustadas com boas estatísticas de precisão, podendo ser utilizadas para a sua estimativa de biomassa de maneira confiável em regiões de Caatinga.

Palavras-chave: Análise de regressão, diâmetro à altura do peito, altura total.

\section{INTRODUCTION}

The Caatinga is present in all Northeastern Brazilian states and in Minas Gerais, totaling $11 \%$ of Brazil's territory or $844,453 \mathrm{~km}^{2}$, with great socio-economic and ecological importance. Among Brazilian biomes, it is considered as a dry tropical formation that presents high species diversity and great heterogeneity regarding the habitat conditions (ARAÚJO, 2005a).

In Pernambuco it occupies the largest phytogeographic area of the state (ANDRADE-LIMA, 2007). It presents a variety of species that distinguish it from the sets that form the other Brazilian typologies, which include an expressive number of rare and endemic taxa, although it is quite altered. The species of this typology present adaptations to the water deficit of the region such as deciduous, succulence, aculeus and thorns, predominance of shrubs and trees of small to medium size, and discontinuous canopy coverage (ANDRADE-LIMA, 2007).

Several studies point out vegetation with different physiognomies ranging from predominantly herbaceous vegetation to arboreal vegetation, with differences in floristic composition between each type (ALBUQUERQUE et al., 2012).

The Caatinga has high floristic diversity for a biome with a strong restriction to growth due to water deficiency. In areas of a few hectares there is generally great dominance of a few species, often two or three of them covering more than $50 \%$ of the density and basal area, and the dominant species are different from one area to another (SAMPAIO, 2010).

The biomass production of the Caatinga is considered low in relation to other biomes. In general, this occurs due to the high temperature and low humidity of the air and precipitation, 
and consequently great losses by evapotranspiration. When the losses are higher than the water uptake by the roots and conduction in the stems, the photosynthetic tissues dehydrate and the stomata close. As a result, water losses are reduced, and also the entry of $\mathrm{CO}_{2}$ and biomass production (MENEZES; SAMPAIO, 2000).

Quantifying the biomass of a shrub-arboreal individual, a shrub-tree species or an ecosystem can be done by direct or indirect methods. Basically, the direct method involves cutting and weighing all the compartments (roots, stem, branches and leaves) of the individuals in a given area, depending on the sampling level that is to be achieved. In spite of presenting more robust results, costs, time, area size, species diversity and the non-cutting ability of most vegetation typologies due to Brazilian legislation make it difficult to implement this method.

Indirect methods based on mathematical equations (regression analysis) become a reliable and robust alternative for estimating biomass, although direct determination is necessary at the first moment to adjust the equations. The comprehensiveness level of the estimates increases using this method, reducing the financial costs of obtaining the shrubtree biomass of an area. In general, model adjustments can be made for each compartment (root, leaf, branch or stem) or the whole set, depending on the level of information one wants to obtain. The chosen mathematical equations should take into account the location where they were developed, included species, the sampling level considered, size and age classes, errors subject to estimates, among others (SOMOGY et al., 2006).

Ecosystem biomass estimates are essential information for issues related to forest management and climate, and are a useful tool in assessing nutrient cycling, carbon sequestration and storage, for example. The important thing is to evaluate the biomass production and distribution of multiple use shrubtree species, aiming at increasing the availability of wood and forage in a certain region, allowing its rational exploitation and contributing to the preservation of native species (GOLLEY et al., 1978).

When it is desired to accurately estimate the total biomass in a given wood ecosystem, it is necessary to know the biomass contribution of the dominant species and to take into account the whole range of the species size or set of species in that area (EAMUS et al., 2000). When considering the total biomass, adjustments in equations are better than the adjustments considering the distinct compartments of the species (stem, branches and leaves) individually, probably because in joining these compartments the deviations of one part are compensated for by the deviations in the opposite direction of another part (SILVA; SAMPAIO, 2008).

There are works for the Caatinga that directly or indirectly estimate both the aboveground and underground biomass of its vegetation (SAMPAIO; FREITAS, 2008; SAMPAIO, 2010; SAMPAIO; COSTA, 2011; MENEZES et al., 2012; CABRAL et al., 2013; COSTA et al., 2014; ALBUQUERQUE et al., 2015; ALVES et al., 2017). But there are few studies that develop biomass equations for species, groups of species and even for different parts of plants in this typology, and the independent variables that have correlated well with this biomass are generally diameter at breast height, diameter at ground level, total height, basal area at ground and chest level, wood density, crown area, number of branches, or the combination of these (SAMPAIO; SILVA, 2005; SILVA;
SAMPAIO, 2008; ALVES JÚNIOR, 2010; SAMPAIO et al. 2010; FERRAZ, 2011; ABREU, 2012; MENDONÇA et al., 2013).

In this context, the objective of this work was to determine the proportions of stem, branches and leaves in relation to the total dry aboveground biomass and to adjust statistical models for estimating the biomass of the main shrub-tree species in an area of Caatinga, thereby contributing to the development of sustainable management and for carbon stock estimates.

\section{MATERIAL AND METHODS}

\subsection{Study area}

The present work was developed in an area of 50 ha within the Fazenda Itapemirim, owned by Agrimex Agroindustrial Excelsior S.A. The farm has a total area of approximately 6,000 ha and is located in the municipality of Floresta, in the state of Pernambuco with access by highways PE-360, BR-232 and BR-110. The headquarters of the farm is situated at the geographical coordinates $8^{\circ} 33^{\prime} 20,9^{\prime \prime} \mathrm{S}$ Latitude and $37^{\circ} 56^{\prime} 27,4^{\prime \prime} \mathrm{W}$ Longitude, about $360 \mathrm{~km}$ from the city of Recife (Figure 1). The study area is part of the Depressão Sertaneja Meridional ecoregion, which is among the regions most impacted by human action with few protected areas. The vegetation can be classified as Woody Steppe-Savanna, being divided into two strata: upper shrub-arboreal, sparse; and the other as lower grassy-woody (Brazilian Institute of Geography and Statistics - IBGE, 2012). The soil is classified as Chronic Luvisol, characterized by being shallow and abruptly changing its texture.

The region's climate is BS'h according to the Köppen climate classification, which refers to a hot semi-arid climate characterized by aridity, water deficiency and unpredictable rainfall ranging from 268 to $1000 \mathrm{~mm}$, and very high average annual temperatures with values ranging from 26 to $28^{\circ} \mathrm{C}$ (IBGE, 2012).

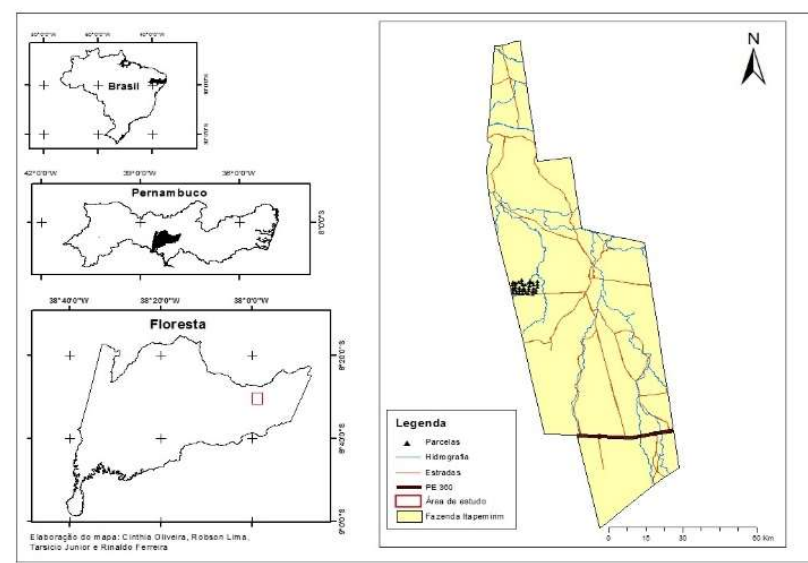

Figure 1. Location of the study area in the municipality of Floresta, state of Pernambuco, Brazil. Source: Lima et al. (2017).

Figura 1. Localização da área de estudo, no município de Floresta, estado de Pernambuco, Brasil. Fonte: Lima et al. (2017).

\subsection{Sample structure and data collection}

The history of the study area shows the establishment and monitoring of 40 permanent plots since 2008, with dimensions of $20 \times 20 \mathrm{~m}\left(400 \mathrm{~m}^{2}\right)$ which are $80 \mathrm{~m}$ apart with $50 \mathrm{~m}$ of the border, totaling a sample area of 1.6 ha. The site is considered preserved (with little cutting history), probably only the removal of forest products for eventual maintenance of fences 
that limit the farm and grazing by animals (mainly goats) in an extensive and uncontrolled way.

All individuals with circumference at $1.30 \mathrm{~m}(\mathrm{CBH}) \geq 6$ $\mathrm{cm}$ were identified and labeled on their $\mathrm{CBH}$ when installing the plots in 2008, aiming to standardize the measurement site. Measurements were remeasured in 2011, 2012 and 2013, and the recruited individuals were inserted in the database, meaning those that reached the minimum $\mathrm{CBH}$ stipulated in the remeasurement years, while the dead and fallen trees were also recorded.

Of the 24 species registered in the study area during the five years, only the eight species with the highest importance value, and consequently those with the highest absolute density were selected based on the phytosociological inventory. These species represent $91.6 \%$ of the total density of the study area, considering that an individual corresponds to a stem that can be obtained from sprouts or bifurcations below $0.30 \mathrm{~m}$ in height. The nomenclatures follow the pattern suggested by Angiosperm Philogeneny Group III (APG III, 2009).

The species were as follows: Anadenanthera colubrina var. cebil (Griseb.) Altschul (angico), Aspidosperma pyrifolium Mart. (pereiro), Bauhinia cheilantha (Bong.) Steud. (mororó), Cnidoscolus quercifolius Pohl (faveleira), Croton heliotropiifolius Kunth (quebra-faca), Mimosa ophthalmocentra Mart. ex Benth (jurema de embira), Mimosa tenuiflora (Willd.) Poir. (jurema preta) and Poincianella bracteosa (Tul.) L.P.Queiroz (catingueira).

\subsection{Data collection}

The biomass collection and determination for the eight species were performed based on the diametric structure found in the forest inventories and which has been applied in studies in this region (ALVES et al., 2017; ABREU, 2012). Each species had individuals sampled in 5 circumference classes at $1.30 \mathrm{~m}$ from the soil $(\mathrm{CBH})$ with amplitudes of $6 \mathrm{~cm}$, from a minimum CBH of $6 \mathrm{~cm}$. The classes and their amplitudes $(\mathrm{cm})$ are as follows: Class I $(6.0-12.0 \mathrm{~cm})$, Class II $(12.1-18.0 \mathrm{~cm})$, Class III (18.1-24.0 cm), Class IV (24.1-30.0 cm) and Class V $(>30.0 \mathrm{~cm})$.

There were 15 individuals cut and their total aboveground biomass was determined for A. colubrina, A. pyrifolium, $C$. quercifolius, $M$. ophthalmocentra, $M$. tenuiflora and $P$. bracteosa, while the same occurred with 30 trees for $B$. cheilantha and $C$. heliotropiifolius. The individuals were cut down in a plot close to the permanent plots. This field has authorization for cutting by the State Environmental Agency of Pernambuco $(C P R H)$, via a state management plan. The individuals were chosen in a random way and avoiding partially cut, burned or fallen plants in order to cover the classes of predicted circumference.

The trees were felled and the individuals were separated into the following compartments: stem, leaves, thin $(\mathrm{CBH}<6$ $\mathrm{cm}$ ) and thick branches $(\mathrm{CBH} \geq 6 \mathrm{~cm})$, and then weighing (wet weight in $\mathrm{kg}$ ) using a portable digital scale. A representative and random sample was drawn for each compartment, which was weighed in the field (wet weight of the sample in $\mathrm{kg}$ ). The sample size ranged from 0.05 to $2.0 \mathrm{~kg}$. For the stems, the sample was represented by a small $20-\mathrm{cm}$-long stele removed at $1.30 \mathrm{~m}$ from the ground.

All wet samples were labeled and taken to the Dendrology Laboratory of the Forest Science Department of UFRPE, where drying was carried out in a forced circulation oven at $70^{\circ} \mathrm{C}$ until stabilization of the dry weight (dry weight of the sample in $\mathrm{kg}$ ). The dry biomass of each aboveground component part of the sampled shrub-tree individuals was obtained by calculations taking into account the direct proportion of the quantities.

\subsection{Proportions of aboveground biomass}

The proportions of dry aboveground biomass (\%) were done for each of the eight species using column charts created in Microsoft Excel (2010). The calculation considered the average biomass proportions of each compartment (stem, thick branches, thin branches and leaves) in relation to the total biomass of all individuals cut down for each species. The information was organized by $\mathrm{CBH}$ classes as previously described, and for grouping all individuals.

\subsection{Equation adjustments}

For adjusting the statistical models, the total dry aboveground biomass $\left(B_{i}\right.$ in $\left.\mathrm{kg}\right)$ data were collected as the dependent variable, while the independent variables were the diameter at breast height $\left(D B H_{i}\right.$ in $\left.\mathrm{cm}\right)$ and total height $\left(H T_{i}\right.$ in $\mathrm{m})$ of the individuals by species. This database also had information from Alves et al. (2017) and Abreu (2012) that were collected from adjacent areas to this study. In total, 30 pairs of data were used for each of the species, except for $M$. tenuiflora, which were only 15 pairs. In total, 225 data pairs were used in adjusting the equations for all species.

Table 1 shows the linear and non-linear models tested to obtain the total dry aboveground biomass equations for each of the studied species. The following conditions were tested for the regression analysis: homogeneity of variance, normality and independence of residues with the Bartlett, Shapiro-Wilk and Durbin-Watson tests, respectively.

We used traditional statistical criteria in selecting the best equation for each of the species: adjusted coefficient of determination $\left(R_{a j}^{2}\right)$, standard error of the estimate in percentage $\left(S_{y x} \%\right)$, graphical analysis of the distribution of residuals $\left(\hat{E}_{i} \%\right)$ and the Furnival Index $(\mathrm{FI} \%)$ corrected by Silva; Bailey (1991) so that it was possible to compare equations with dependent variables of different natures. The coefficient of determination expresses the amount of the total variation explained by the regression, where the higher its value, the better the equation. However, the corrected Furnival Index gives an idea of the dispersion between the observed and estimated values, so the smaller it is, the better the equation (SCHNEIDER et al., 2009). The Levenberg-Marquardt algorithm was used to fit non-linear statistical models. All data analyzes were performed through IBM SPSS 20.0, SAS 9.0 and Microsoft Excel (2010) programs.

\section{RESULTS}

\subsection{Biomass proportions}

A. colubrina, A. pyrifolium, C. quercifolius, M. tenuiflora and $P$. bracteosa presented a higher stem proportion in relation to the other compartments in all $\mathrm{CBH}$ classes, except for class $\mathrm{V}$ for A. pyrifolium and P. bracteosa. The proportion of thin branches and leaves is greater than that of thick branches in the lower classes, but this pattern is reversed with the increase in $\mathrm{CBH}$. The average total proportion was approximately $50 \%$ for stem, between 20 and $25 \%$ for thick branches, between 15 and $25 \%$ for thin branches and 5\% for leaves (Figure 2). 
Table 1. Mathematical models tested to obtain equations of dry aboveground biomass for eight species in an area of Caatinga in the municipality of Floresta, Pernambuco, Brazil.

Tabela 1. Modelos estatísticos testados para obtenção de equações de biomassa total seca acima do solo para oito espécies em uma área de Caatinga no município de Floresta, Pernambuco, Brasil.

\begin{tabular}{ccc}
\hline Number & Model & Author \\
\hline 1 & $Y_{i}=\beta_{0} *\left(D B H_{i}^{\beta_{1}}\right) *\left(H T_{i}^{\beta_{2}}\right)+\varepsilon_{i}$ & Shumacher-Hall \\
2 & $\ln Y_{i}=\beta_{0}+\beta_{1} * \ln \left(D B H_{i}\right)+\beta_{2} * \ln \left(H T_{i}\right)+\varepsilon_{i}$ & Shumacher-Hall (linear) \\
3 & $Y_{i}=\beta_{0}+\beta_{1} *\left(D B H_{i}^{2} * H T_{i}\right)+\varepsilon_{i}$ & Spurr \\
4 & $\ln Y_{i}=\beta_{0}+\beta_{1} * \ln \left(D B H_{i}^{2} * H T_{i}\right)+\varepsilon_{i}$ & Spurr (linear) \\
5 & $Y_{i}=\beta_{0} *\left[1-\exp \left(-\beta_{1} * D B H_{i}\right)\right]^{\beta_{2}}+\varepsilon_{i}$ & Chapman-Richards \\
6 & $Y_{i}=\beta_{0} *\left(D B H_{i}\right)^{\beta_{1}}+\varepsilon_{i}$ & Power \\
7 & $Y_{i}=\beta_{0} *\left(D B H^{2}\right)^{\beta_{1}}+\varepsilon_{i}$ & Power \\
8 & $Y_{i}=\beta_{0} *\left(D B H_{i}^{2} * H T_{i}\right)^{\beta_{1}}+\varepsilon_{i}$ & Power \\
\hline
\end{tabular}

In which: $Y_{i}=$ total dry aboveground biomass $(\mathrm{kg}) ; \beta_{0}, \beta_{1}$ and $\beta_{2}=$ coefficients of the models; $D B H=$ diameter at breast height $(\mathrm{cm}) ; H T=$ total height (m) and $\varepsilon_{i}=$ random error.

M. ophthalmocentra presented a different pattern from the other species. The proportion of stem biomass did not exceed $45 \%$ in the five classes, being less than $40 \%$ in the majority. The proportions of thick branches increase and those of thin branches and leaves decrease along the classes, but the proportion of thin branches is superior to that of the stem in the first two classes. This species presents identical proportions of stem and thin branches $(38 \%)$ in the total biomass average, and only $20 \%$ of thick branches and close to $3 \%$ for leaves (Figure 2 ).

$B$. cheilantha and $C$. heliotropiifolius are species that did not present great dimensions. The proportions indicate that $B$. cheilantha has very close stem and branch proportions (approximately 45\%) and thick branches and leaves not exceeding 10 and 5\%, respectively. However, the stem biomass for $C$. heliotropiifolius is above $50 \%$, and the thin branches close to $35 \%$, while the thick branches and leaves present the same pattern as $B$. cheilantha (Figure 2).

\subsection{Biomass equations}

The model adjustment results with all the coefficients of the significant equations are presented in Table $2(p \leq 0.05)$ as well as the adjusted coefficient of variation $\left(R_{a j}^{2}\right)$ greater than 0.70 (inclusion criteria). The adjustment result of four models (5, 6, 7 and 8) were selected for $A$. colubrina through the inclusion criteria, but the best equation was that of the Chapman-Richards model (5), because it presented greater $R_{a j}^{2}$ and lower $F I \%$ in relation to the others (Table 2), as well as more homogeneous residuals distribution.

The model adjustment results presented in Table 2 for A.pyrifolium and $B$. cheilantha show great similarity between the precision statistics of equations 1 and 8 , in addition to discrete variation between the residuals distribution. The two equations ( 1 and 8 ) with their respective coefficients can be used to estimate the total dry aboveground biomass soil for both species. However, due to the need to recommend the most accurate equation for each of the eight studied species, equation 8 is chosen for A.pyrifolium because it presents slightly superior $R_{a j}^{2}$, and equation 1 for $B$. cheilantha due to the lower $F I \%$ value.

Of the five models selected for $C$. quercifolius within the inclusion criteria $(3,4,6,7$ and 8$)$, three models $(6,7$ and 8$)$ presented better $R_{a j}^{2}(\%), F I(\%)$ and residuals, but were practically identical in the equation adjustments. Due to these similarities, the recommended equation to calculate the total dry biomass estimate was 6 because it did not use the independent HT variable which was difficult to obtain, and the combination of the independent variable diameter at breast height squared $\left(D B H^{2}\right)$, resulting in less slowness for the total dry aboveground biomass estimates for this species (Table 2).

C. heliotropiifolius had the models $1,2,3,4$ and 8 analyzed, but the Shumacher-Hall equation is suggested for the biomass estimation, since it presented lower FI (\%) and more homogeneous residuals. From the five selected models for $M$. ophthalmocentra (1, 2, 5, 6 and 7), only 1 and 2 deserve attention because they present the best precision statistics, and equation 2 is indicated for estimating the biomass of this species because it has smaller $F I(\%)$ and more homogeneous residuals.

The selected models for M. tenuiflora were 3, 4, 6 and 7, and equations 6 and 7 presented identical and more accurate statistics than the others. In this case, the most suitable for estimating biomass is equation 6 , since it does not need to make combinations with the independent variable, facilitating estimation of the dependent variable. For P. bracteosa the data were better fitted to the models $1,3,6,7$ and 8 , but equation 3 is indicated for this species because it presents greater $R_{a j}^{2}$, lower FI (\%)(Table 2) and more homogeneous residuals than the other equations.

The best results for the set of species were those from models 2 and 4. Equation 2 was chosen because it presented higher $R_{a j}^{2}$ and lower FI (\%).

Table 3 presents the nine best equations suggested for estimating total dry aboveground biomass for the main Caatinga species.

Figure 3 shows the graphical residuals distribution only for the nine best equations selected for estimating the total dry aboveground biomass for each analyzed species and for the grouping of species.

\section{DISCUSSION}

\subsection{Biomass proportions}

When analyzing the average proportions of total dry aboveground biomass (\%) in each compartment, it can be observed that the range of variation in the biomass percentages of the compartments in relation to the whole is smaller than in the absolute values, showing that these species grow proportionally, closely, and have similarity between some species (Figure 2). 

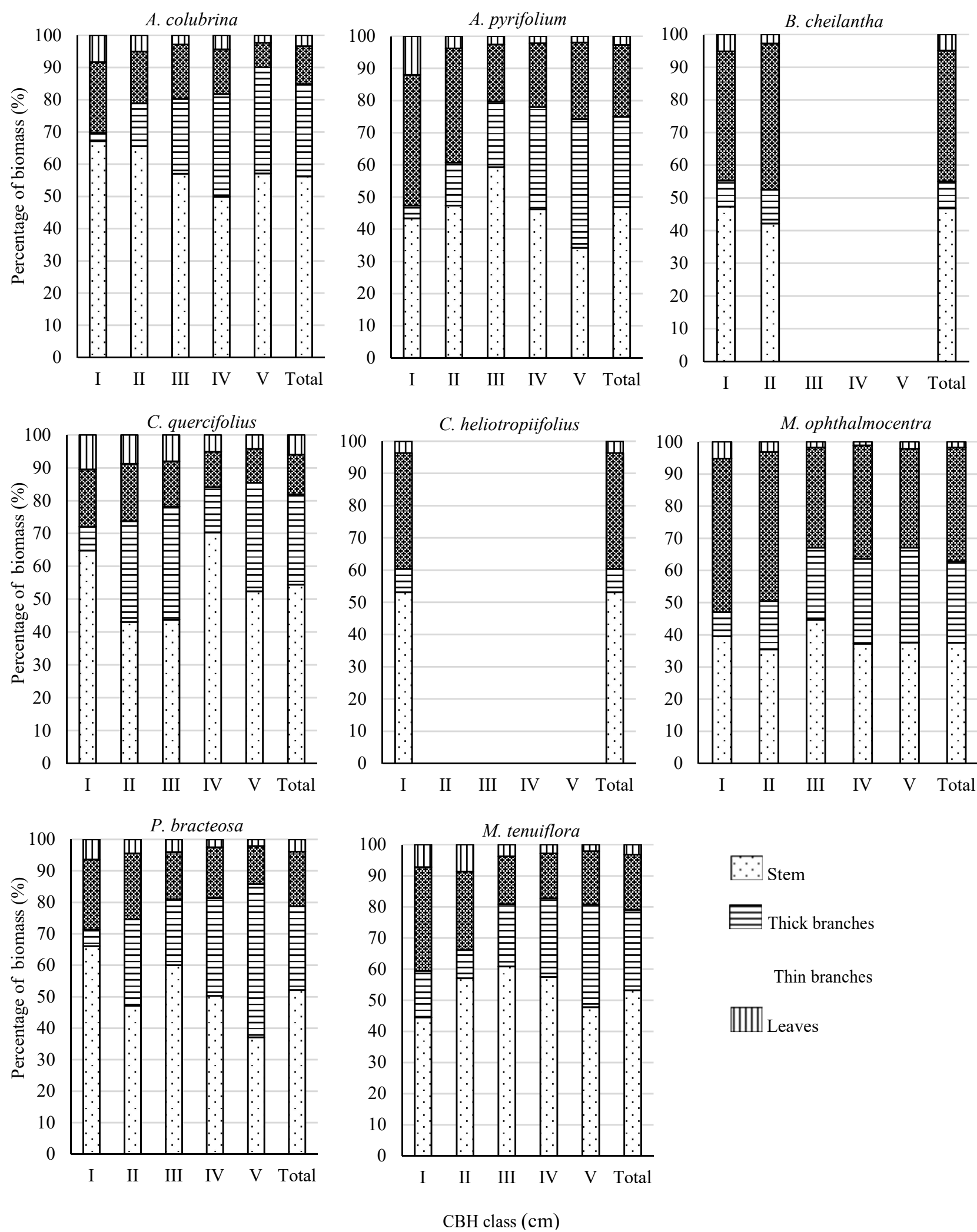

Thin branches

||ाIII Leaves

Figure 2. Proportion of total dry aboveground biomass (\%) in each compartment per $\mathrm{CBH}$ class $(\mathrm{cm})$ for the eight analyzed species in an area of Caatinga in the municipality of Floresta, Pernambuco, Brazil.

Figura 2. Proporção de biomassa seca total acima do solo (\%) em cada compartimento por classe de CAP (cm) para as oito espécies analisadas em uma área de Caatinga no município de Floresta, Pernambuco, Brasil. 


\section{Equações de biomassa para espécies da Caatinga}

Table 2. Number, parameters and statistics of the selected equations for calculating total dry aboveground biomass for each of the eight species in an area of Caatinga in the municipality of Floresta, Pernambuco, Brazil.

Tabela 2. Número, coeficientes e estatísticas das equações de biomassa total seca acima do solo selecionadas para cada uma das oito espécies em uma área de Caatinga no município de Floresta, Pernambuco, Brasil.

\begin{tabular}{|c|c|c|c|c|c|c|c|c|}
\hline Species & Model & $\beta_{0}$ & $\beta_{1}$ & $\beta_{2}$ & $R_{\text {adjusted }}^{2}$ & $S_{y x}$ & $S_{y x} \%$ & $F I \%$ \\
\hline & 5 & 48,7255 & 0,1435 & 2,4096 & 0,89 & 3,20 & 20,69 & 32,5 \\
\hline Anadenanthera & 6 & 1,7527 & 1,1265 & - & 0,86 & 3,55 & 22,94 & 36,6 \\
\hline \multirow[t]{2}{*}{ colubrina } & 7 & 1,7531 & 0,5632 & - & 0,86 & 3,55 & 22,94 & 36,6 \\
\hline & 8 & 1,4905 & 0,4069 & - & 0,84 & 3,83 & 24,75 & 39,5 \\
\hline \multirow{4}{*}{$\begin{array}{l}\text { Aspidosperma } \\
\text { pyrifolium }\end{array}$} & 1 & 0,7271 & 0,8176 & 0,6229 & 0,74 & 2,18 & 27,01 & 42,4 \\
\hline & 6 & 1,0110 & 1,1361 & - & 0,71 & 2,28 & 28,25 & 45,0 \\
\hline & 7 & 1,0109 & 0,5681 & - & 0,71 & 2,28 & 28,25 & 45,0 \\
\hline & 8 & 0,7858 & 0,4550 & - & 0,75 & 2,15 & 26,64 & 42,5 \\
\hline \multirow{6}{*}{$\begin{array}{l}\text { Bauhinia } \\
\text { cheilantha }\end{array}$} & 1 & 0,0699 & 2,2115 & 0,8155 & 0,97 & 0,18 & 12,09 & 19,0 \\
\hline & 2 & $-2,7776$ & 2,1672 & 0,9313 & 0,94 & 0,14 & 65,11 & 18,6 \\
\hline & 4 & $-2,8746$ & 1,0523 & - & 0,94 & 0,14 & 64,41 & 18,7 \\
\hline & 6 & 0,1543 & 2,4831 & - & 0,94 & 0,27 & 17,87 & 28,5 \\
\hline & 7 & 0,1543 & 1,2416 & - & 0,94 & 0,27 & 17,87 & 28,5 \\
\hline & 8 & 0,0568 & 1,0531 & - & 0,97 & 0,19 & 12,54 & 20,0 \\
\hline \multirow{5}{*}{$\begin{array}{l}\text { Cnidoscolus } \\
\text { quercifolius }\end{array}$} & 3 & 3,9444 & 0,0186 & - & 0,79 & 2,41 & 27,20 & 43,4 \\
\hline & 4 & $-0,6664$ & 0,5237 & - & 0,72 & 0,35 & 17,52 & 46,2 \\
\hline & 6 & 0,6064 & 1,4216 & - & 0,82 & 2,26 & 25,51 & 40,7 \\
\hline & 7 & 0,6064 & 0,7108 & - & 0,82 & 2,26 & 25,51 & 40,7 \\
\hline & 8 & 0,4896 & 0,5387 & & 0,82 & 2,29 & 25,78 & 41,1 \\
\hline \multirow{5}{*}{$\begin{array}{c}\text { Croton } \\
\text { heliotropiifolius }\end{array}$} & 1 & 0,1868 & 1,2764 & 0,9401 & 0,76 & 0,38 & 18,96 & 29,7 \\
\hline & 2 & $-1,6887$ & 1,2224 & 0,9761 & 0,71 & 0,20 & 31,81 & 29,3 \\
\hline & 3 & 0,6522 & 0,0582 & - & 0,76 & 0,38 & 19,15 & 30,5 \\
\hline & 4 & $-1,5518$ & 0,7158 & - & 0,70 & 0,20 & 32,21 & 30,2 \\
\hline & 8 & 0,2219 & 0,7065 & - & 0,76 & 0,38 & 19,11 & 30,5 \\
\hline \multirow{5}{*}{$\begin{array}{c}\text { Mimosa } \\
\text { ophthalmocentra }\end{array}$} & 1 & 6,0137 & 1,7250 & $-1,338$ & 0,90 & 3,38 & 19,80 & 31,0 \\
\hline & 2 & 1,1118 & 1,7371 & $-0,9536$ & 0,88 & 0,23 & 9,04 & 30,0 \\
\hline & 5 & 43,6748 & 0,2103 & 2,9584 & 0,75 & 5,47 & 32,04 & 50,3 \\
\hline & 6 & 2,2018 & 1,1066 & - & 0,71 & 5,83 & 34,16 & 54,5 \\
\hline & 7 & 2,2016 & 0,5533 & - & 0,71 & 5,83 & 34,16 & 54,5 \\
\hline \multirow{4}{*}{$\begin{array}{l}\text { Mimosa } \\
\text { tenuiflora }\end{array}$} & 3 & 3,0407 & 0,0458 & - & 0,89 & 3,22 & 22,12 & 34,11 \\
\hline & 4 & $-1,6100$ & 0,7850 & - & 0,92 & 0,25 & 10,58 & 29,45 \\
\hline & 6 & 0,5084 & 1,7121 & - & 0,94 & 2,44 & 16,79 & 25,90 \\
\hline & 7 & 0,5084 & 0,8561 & - & 0,94 & 2,44 & 16,79 & 25,90 \\
\hline \multirow{5}{*}{$\begin{array}{c}\text { Poincianella } \\
\text { bracteosa }\end{array}$} & 1 & 0,6221 & 1,1061 & 0,6840 & 0,83 & 4,38 & 24,40 & 38,3 \\
\hline & 3 & 6,6205 & 0,0341 & - & 0,85 & 4,20 & 23,40 & 37,3 \\
\hline & 6 & 0,9765 & 1,5126 & - & 0,75 & 5,41 & 30,12 & 48,0 \\
\hline & 7 & 0,9767 & 0,7563 & - & 0,75 & 5,41 & 30,12 & 48,0 \\
\hline & 8 & 0,6173 & 0,5957 & & 0,84 & 4,33 & 24,08 & 38,4 \\
\hline \multirow{7}{*}{ All species } & 1 & 0,8905 & 1,2189 & 0,2333 & 0,74 & 4,98 & 47,63 & 78,0 \\
\hline & 2 & $-1,2884$ & 1,6102 & 0,4343 & 0,85 & 0,43 & 23,46 & 42,9 \\
\hline & 4 & $-1,4991$ & 0,7290 & - & 0,84 & 0,44 & 23,69 & 43,5 \\
\hline & 5 & 55,8948 & 0,1176 & 2,2982 & 0,74 & 4,92 & 47,11 & 77,2 \\
\hline & 6 & 0,9867 & 1,3692 & - & 0,73 & 5,03 & 48,12 & 79,0 \\
\hline & 7 & 0,9867 & 0,6846 & - & 0,73 & 5,03 & 48,12 & 79,0 \\
\hline & 8 & 0,8471 & 0,5034 & - & 0,73 & 5,06 & 48,39 & 79,4 \\
\hline
\end{tabular}

Table 3. Mathematical equations suggested for estimating total dry aboveground biomass in an area of Caatinga in the municipality of Floresta, Pernambuco, Brazil.

Tabela 3. Equações matemáticas sugeridas para a estimativa da biomassa aérea seca em uma área de Caatinga, no município de Floresta, Pernambuco, Brasil.

\begin{tabular}{lcccc}
\hline \multicolumn{1}{c}{ Species } & Equation & $R_{a j}^{2}$ & $S_{y x}(\%)$ & $F I(\%)$ \\
\hline Anadenanthera colubrina & $B s_{i}=48.7255 *\left[1-\exp \left(-0.1435 * D B H_{i}\right)\right]^{2.4096}$ & 0.89 & 20.69 & 32.5 \\
Aspidosperma pyrifolium & $B s_{i}=0.7858 *\left(D B H_{i}^{2} * H T_{i}\right)^{0.4550}$ & 0.75 & 26.64 & 42.5 \\
Bauhinia cheilantha & $B s_{i}=0.0669 *\left(D B H_{i}^{2.2115}\right) *\left(H T_{i}^{0.8155}\right)$ & 0.97 & 12.09 & 19.0 \\
Cnidoscolus quercifolius & $B s_{i}=0.6064 *\left(D B H_{i}\right)^{1.4216}$ & 0.82 & 25.51 & 40.6 \\
Croton heliotropiifolius & $B s_{i}=0.1868 *\left(D B H_{i}^{1.2764}\right) *\left(H T_{i}^{0.9410}\right)$ & 0.76 & 18.96 & 29.7 \\
Mimosa ophthalmocentra & $\ln B s_{i}=1.1118+1.7371 * \ln \left(D B H_{i}\right)-0.9536 * \ln \left(H T_{i}\right)$ & 0.88 & 9.04 & 30.0 \\
Mimosa tenuiflora & $B s_{i}=0.5084 *\left(D B H_{i}\right)^{1.7121}$ & 0.94 & 16.79 & 25.9 \\
Poincianella bracteosa & $B s_{i}=6.6205+0.0341 *\left(D B H_{i}^{2} * H T_{i}\right)$ & 0.85 & 23.40 & 37.3 \\
All species & $\ln B s_{i}=-1.2884+1.6102 * \ln \left(D B H_{i}\right)+0.4343 * \ln \left(H T_{i}\right)$ & 0.85 & 23.46 & 42.9 \\
\hline
\end{tabular}

In which: $B S=$ total dry aboveground biomass $(\mathrm{kg}) ; D B H=$ diameter at breast height $(\mathrm{cm}) ; H T=$ total height $(\mathrm{m}) ; R_{a j}^{2}(\%)=$ adjusted coefficient of determination in percentage; $S_{y x}(\%)=$ standard error of the estimate in percentage and $F I(\%)=$ Furnival Index in percentage. 

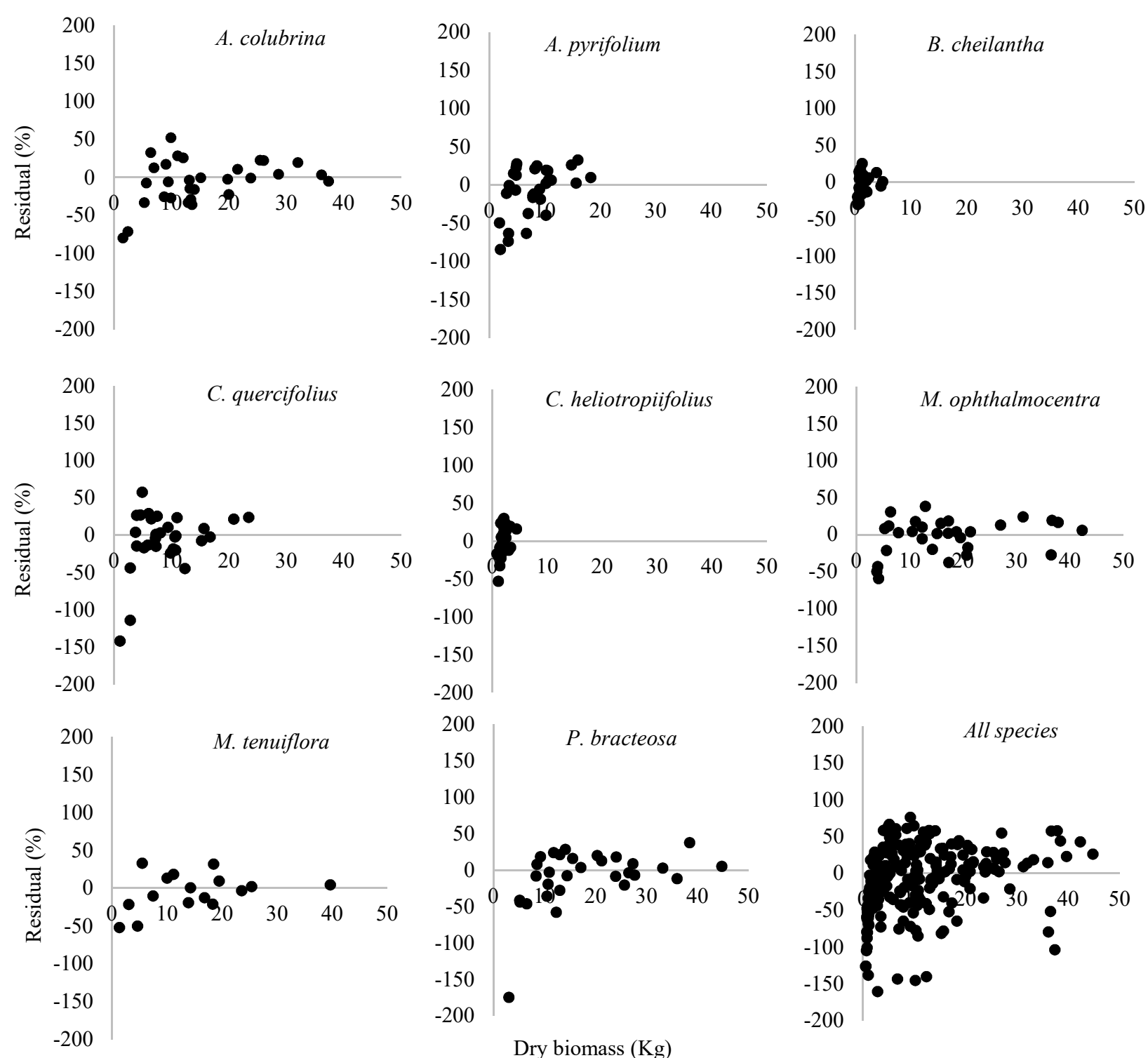

Figure 3. Graphical distribution of the residuals of the selected equations for total dry aboveground biomass for each of the eight species and for all species in an area of Caatinga in the municipality of Floresta, Pernambuco, Brazil.

Figura 3. Distribuição gráfica dos resíduos das equações selecionadas para biomassa seca total acima do solo para cada uma das oito espécies e para todas as espécies em uma área de Caatinga no município de Floresta, Pernambuco, Brasil.

In general, the average proportions of total dry aboveground biomass $(\%)$ in each compartment vary due to the growth pattern of each species, and it is not prudent to attribute similarities between genera and botanical families due to the specific characteristics of each species, mainly for M. ophthalmocentra.

Comparing both the absolute values and the biomass proportions between different species and/or regions should be done carefully, since other factors in addition to the different methodologies used may influence the production. For Barichello et al. (2005), in addition to environmental factors, the accumulation of biomass can be influenced by plant factors, especially those affecting photosynthesis and respiration (luminosity, temperature, $\mathrm{CO}_{2}$ concentration in the air, water concentration, soil fertility, diseases, age, structure and arrangement of leaves, distribution and behavior of stomata, chlorophyll content, and accumulation of carbohydrates).
Studies on the stocks and production rates and biomass accumulation in the Caatinga vegetation are essential information for assessing wood production capacity, the fallow time of itinerante cultivation, carbon sequestration capacity and the productivity potential of the systems, as well as their respective financial gains (SAMPAIO; FREITAS, 2008).

\subsection{Biomass equations}

The adjustment of the models for each of the eight analyzed species resulted in different results, and the majority overestimated the biomass of the trees with lower mass (Figure 3). This large variation can be attributed to the shape, height, crown size, number and size of the individuals of the shrubtree species of the Caatinga or the remnants of other successional stages.

The results found when compared with adjusted equations in other studies for the same species or other species in different regions of the Caatinga are considered within the 
registered limits (SAMPAIO; SILVA, 2005; SILVA; SAMPAIO, 2008; SAMPAIO et al., 2010; ALVES JR., 2010; FERRAZ, 2011; ABREU, 2012; MENDONÇA et al., 2013).

The worst results for precision statistics $\left(R_{a j}^{2}\right.$ and $\left.F I\right)$ were observed for the $A$. pyrifolium species regarding the 8 species analyzed (Table 2), corroborating Abreu (2012) who recorded approximately $78 \%$ for $R_{a j}^{2}$ and $19 \%$ for $S_{y x}(\%)$ for the two best equations. When observing that the present study used the data used by Abreu (2012) plus other collected samples, we can infer that the increase in sample intensity does not always increase the accuracy of the equations. According to Ferraz (2011), this greater or lesser precision of the equations is related to the characteristics of the Caatinga shrub-tree species, since they present a great variation in form/shape, height, number and size of the branches, and if woody material is considered in the evaluations.

$B$. cheilantha was the species that presented the highest values of $R_{a j}^{2}$ and the lowest $F I \%$ values in relation to the other analyzed species. This result is due to a high correlation between the independent and the dependent variables, because as the diameter increases, the dry mass also increases linearly and positively.

According to Carvalho (2010), B. cheilantha is a shrubtree species in which the largest trees reach about $7.80 \mathrm{~m}$ in height and $30 \mathrm{~cm}$ of DBH in adult age, with the stem being irregular, very short or bifurcated. The individuals' pattern in the study area differs from what is recorded in the literature for this species, since the analyzed individuals did not present diameters, height or dry biomass above $4.1 \mathrm{~cm}, 4.9$ and $5.0 \mathrm{~kg}$, respectively, and most of them were concentrated in the Class I CBH $(\mathrm{cm})$, with a low variation between the dependent and independent variables, which may suggest that they are young individuals.

For M. ophthalmocentra, Sampaio et al. (2010) adjusted power equations with the best dry biomass estimation option among linear, quadratic, exponential and logarithmic models, but the determination coefficient results were lower for the independent variables of isolated $\mathrm{DBH}(\mathrm{cm}), \mathrm{DBH}(\mathrm{cm})$ and $\mathrm{H}$ $(\mathrm{m}), \mathrm{DBH}(\mathrm{cm})$ and crown area $\left(\mathrm{m}^{2}\right)$, than those found in this study of 81,73 and $59 \%$, respectively; however, the error estimates for these equations are not mentioned. These same authors indicated the best power equation for M. tenuiflora using only DBH as an independent variable in two Caatinga areas in Serra Talhada and Sertânia/PE, corroborating the results of this study.

For $P$. bracteosa, the results of the precision statistics corroborate those found by Ferraz (2011) when studying dry biomass estimates of 30 individuals in an area of Caatinga (Floresta/PE), obtaining 24 equations with errors between 18.06 and $32.42 \%$ and $R_{a j}^{2}$ higher than $76 \%$, reaching $93.5 \%$.

In the case of the species $C$. quercifolius and $M$. tenuiflora there was the possibility of choosing between a model with independent variables that are easy to obtain in relation to one with greater difficulty, without compromising the precision of the estimates. This possibility is a widely-used strategy in regression analysis studies in the forest area, since the addition of these variables in the equation, even when they present better statistics, does not always compensate for the encumbrance and longer data collection time.

A.pyrifolium, B. cheilantha, C. heliotropiifolius and $P$. bracteosa presented close precision statistics among the best equations, so the use of the other equations is not ruled out, and the choice criterion also took into account the researchers' preference due to the little difference between the statistical criteria. When comparing univariate and multivariate statistical methods in selecting 21 independent variables in volumetric models for Leucaena leucocephala (Lam.) de Wit, Araújo (2005) concluded that the subjective judgment of the researcher is a criterion that must be taken into account when deciding on selecting the variables in mathematical modeling, since statistics and mathematical processes treat all variables as being equal in terms of cost and ease of measurement.

The general equation presented better precision statistics when compared to the species A. pyrifolium, C. quercifolius and $C$. heliotropiifolius. This can be attributed to compensating the biomass deviations of one species from another species, but this result does not prevent using specific equations for each species.

In the residuals' distribution the tendency to overestimate biomass in the trees with lower mass was evident, as well as in the great majority of the species which were analyzed separately.

\section{CONCLUSIONS}

The proportions of dry aboveground biomass for $A$. colubrina, A. pyrifolium, B. cheilantha, C. quercifolius, $C$. heliotropiifolius, $M$. ophthalmocentra, $M$. tenuiflora and $P$. bracteos $a$ were determined for both their compartments (stem, leaves, thick and thin branches) as well as the total.

Dry aboveground biomass equations were developed for A. colubrina, A pyrifolium, B. cheilantha, C. quercifolius, $C$. heliotropiifolius, $M$. ophthalmocentra, $M$. tenuiflora and $P$. bracteosa with reasonable accuracy statistics for all these species, and can be used to reliably estimate this variable in Caatinga regions with similar characteristics to this study.

This information can contribute to the quantification of carbon and nutrient stocks in Caatinga areas.

\section{REFERENCES}

ABREU, J. C. Modelagem de biomassa e de nutrientes de espécies da caatinga no município de Floresta-PE. 2012. 111f. Dissertação (Mestrado em Ciências Florestais) - Universidade Federal Rural de Pernambuco, 2012.

ALBUQUERQUE, U. P.; ARAÚJO E. L.; EL-DEIR, A. C. A.; LIMA, A. L. A.; SOUTO, A.; BEZERRA, B. M.; FERRAZ, E. M. N.; FREIRE, E. M. X.; SAMPAIO, E. V. S. B.; LAS-CASAS, F. M. G; MOURA, G. J. B.; PEREIRA, G. A.; MELO, J. G.; RAMOS, M. A.; RODAL, M. J. N.; SCHIEL, N.; LYRA-NEVES, R. M.; ALVES, R. R. N.; AZEVEDO-JÚNIOR, S. M.; TELINO JÚNIOR, W. R.; SEVERI, W. Caatinga revisited: Ecology and Conservation of an Important Seasonal Dry Forest. The Scientific World Journal, n. 205182, p. 1-18, ago. 2012. DOI: https://doi.org/10.1100/2012/205182.

ALBUQUERQUE, E. R. G. M.; SAMPAIO, E. V. S. B.; OPAREYN, F. G. C.; ARAÚJO, E. L. Root biomass under stem bases and at different distances from trees. Journal of Arid Environments, n. 116, p. 82-88, mai. 2015. DOI: https://doi.org/10.1016/j.jaridenv.2015.02.003

ALVES JUNIOR, F. T. Estrutura, biomassa e volumetria de uma área de Caatinga, Floresta-PE. 2010. 151f. Tese (Doutorado em Ciências Florestais) - UFRPE, 2010.

ALVES, A. R.; FERREIRA, R. L. C.; SILVA, J. A. A.; DUBEUX JÚNIOR, J. C. B.; OSAJIMA, J. A.; HOLANDA, A. C. Conteúdo de nutrientes da biomassa e 
eficiência nutricional em espécies da Caatinga. Ciência Florestal, Santa Maria. v. 27, p. 377-390, 2017. DOI: http: //dx.doi.org/10.5902/1980509827686

ANDRADE-LIMA, D. Estudos Fitogeográficos de Pernambuco. Anais da Academia Pernambucana de Ciência Agronômica, Recife, v. 4, p. 243-274, 2007.

ANGIOSPERM PHYLOGENY GROUP III (APG III) An update of the angiosperm phylogeny group classification for the orders and families of flowering plants. Botanical Journal of the Linnean Society, London, v.161, p.105121, out. 2009. DOI: 10.1111/j.1095-8339.2009.00996.x.

ARAUJO, E. L. Estresse abióticos e bióticos como forças modeladoras da dinâmica de populações vegetais da caatinga. In: NOGUEIRA, R. J. M. C.; ARAÚJO, E. L.; WILLADINO L. G.; CAVALCANTI, U. M. T. (Eds.) Estresses ambientais: danos e benefícios em plantas. Recife: Imp. Universitária da UFRPE, 2005a. p. 50-64.

ARAUJO, A. G. Comparação entre métodos univariados e multivariados na seleção de variáveis independentes, na construção de tabelas volumétricas para Leucaena leucocephala (Lam) de Wit. 2005. 91f. Dissertação (Mestrado em Biometria) - UFRPE, 2005b.

BARICHELLO, L. R.; SCHUMACHER, M. V.; VOGEL, H. L. M. Quantificação da biomassa de um povoamento de Acacia mearnsii de Wild. na região sul do Brasil. Revista Ciência Florestal, Santa Maria, v. 15, n. 2, p. 129-135, 2005. DOI: http: //dx.doi.org/10.5902/198050981830

ABRAL, G. A. L.; SAMPAIO, E. V. S. B.; ALMEIDACORTEZ, J. S. Estrutura espacial e biomassa da parte aérea em diferentes estádios sucessionais de caatinga, em Santa Terezinha, Paraíba. Revista Brasileira de Geografia Física, Recife, v. 6, n. 3, p. 566-574, 2013.

CARVALHO, P. E. R. Espécies arbóreas brasileiras. 1. ed. v.4. Colombo: Embrapa Florestas, 2010. 644p.

COSTA, T. L.; SAMPAIO, E. V. S. B.; SALES, M. F.; ACCIOLY, L. J. O.; ALTHOFF, T. D.; PAREYN, F. G. C.; ALBUQUERQUE, E. R. G.; MENEZES, R. S. C. Root and shoot biomasses in the tropical dry forest of semi-arid Northeast Brazil. Plant \& Soil, v. 378, p. 113-123, 2014. DOI: https://doi.org/10.1007/s11104-013-2009-1.

EAMUS, D.; McGUINNESS, K.; BURROWS, W. Review of Allometric Relationships for Estimating Woody Biomass for Queensland, the Northern Territory and Western Australia. Australian Greenhouse Office, n. 5, $2000 . \quad$ Disponível em http://www.fullcam.com/FullCAMServer/Help/reps/TR5 A\%20Review\%20of\%20Allometric\%20Relationships\%2 0for $\% 20$ Estimating $\% 20$ Woody $\% 20$ Biomass $\% 20$ for $\% 20$ Queensland,\%20the\%20Northern\%20Territory\%20and\% 20Western\%20Australia.pdf. Acesso em: 29 jun. 2016

FERRAZ, J. S. F Análise da vegetação de Caatinga arbustivo-arbórea em Floresta, PE, como subsidio ao manejo florestal. 2011. 134f. Tese (Doutorado em Ciências Florestais) - Universidade Federal Rural de Pernambuco, 2011.

GOLLEY, F. B.; McGUINNESS, J. T.; CLEMENTS, R. G.; CHILD, G. I.; DEUVER, M. J. Ciclagem de minerais em um ecossistema de floresta tropical úmida. São Paulo, EPU-EdUSP, 1978. 256p.

INSTITUTO BRASILEIRO DE GEOGRAFIA E ESTATÍSTICA (IBGE). Manual técnico da vegetação brasileira. 2 ed. Rio de Janeiro, 2012. 271p.
LIMA, R. B.; BUFALINO, L.; ALVES JUNIOR, F. T.; SILVA, J. A. A; FERREIRA, R. L. C. Diameter distribution in a Brazilian tropical dry forest domain: predictions for the stand and species. Anais da Academia Brasileira de Ciências. v. 89, p. 1189-1203, abr/jun. 2017. DOI: http://dx.doi.org/10.1590/00013765201720160331.

MENDONÇA, A. V. R.; SOUZA, J. S.; GIULIETTI, A. M.; DEN BER, C. V. Estimação de biomassa aérea da caatinga do norte da Bahia. Pesquisa Florestal Brasileira, Colombo, v. 33, n. 76, p. 355-368, 2013. DOI: http://dx.doi.org/10.4336/2013.pfb.33.76.579

MENEZES, R. S. C.; SAMPAIO, E. V. S. B. Agricultura sustentável no semiárido nordestino. In OLIVEIRA, T. S. et al. (Eds.). Agricultura, sustentabilidade e o semiárido. Fortaleza: Sociedade Brasileira de Ciência do Solo, 2000, p. 20-46.

MENEZES, R. S. C.; SAMPAIO, E. V. S. B.; GIONGO, V.; PÉREZ-MARIN, A. M. Biogeochemical cycling in terrestrial ecosystems of the Caatinga Biome. Brazilian Journal of Biology, v. 72, n. 3, p. 643-653, 2012. DOI: http://dx.doi.org/10.1590/S1519-69842012000400004.

SAMPAIO, E. V. S. B.; SILVA, G. Biomass equations for Brazilian semiarid caatinga plants. Acta Botânica Brasílica. v. 4, n. 19, p. 935-943, 2005. DOI: http://dx.doi.org/10.1590/S0102-33062005000400028

SAMPAIO, E. V. S. B.; FREITAS, A. D. S. Produção de biomassa na vegetação nativa do semi-árido nordestino. In: MENEZES, R. S. C.; SAMPAIO, E. V. S. B.; SALCEDO, I. H. (Orgs.). Fertilidade do solo e produção de biomassa no semi-árido. Recife: Editora Universitária UFPE, 2008. v. 1, p. 11-26.

SAMPAIO, E. V. S. Características e potencialidades. In: GARIGLIO, M. A. et al. (Orgs.) Uso sustentável e conservação dos recursos florestais da Caatinga. Brasília: Serviço Florestal Brasileiro, 2010. p. 29-42.

SAMPAIO, E. V. S. B.; GASSON, P.; BARACAT, A.; CUTLER, D. PAREYN, F.; LIMA, K. C. Tree biomass estimation in regenerating areas of tropical dry vegetation in northeast Brazil. Forest Ecology and Management, n. 259, p. 1135-1140, 2010. DOI: https://doi.org/10.1016/j.foreco.2009.12.028.

SAMPAIO, E. V. S.; COSTA, T. L. Estoques e Fluxos de Carbono no Semi-Árido Nordestino: Estimativas Preliminares. Revista Brasileira de Geografia Física, Recife, v. 6, p. 1275-1291, 2011.

SCHNEIDER, P. R.; SCHNEIDER, P. S. P.; SOUZA, C. A. $\mathrm{M}$. S. Análise de regressão aplicada à Engenharia Florestal. 2. ed. Santa Maria: UFSM/FACOS, 2009. 566p.

SILVA, J. A. A.; BAILEY, R. L. Considerações teóricas sobre o uso correto do índice de Furnival na seleção de equações volumétricas. Revista Árvore, v.15, n.3, p. 323-327, 1991.

SILVA, G. C.; SAMPAIO, E. V. S. B. Biomassas de partes aéreas em plantas da caatinga. Revista Árvore, Viçosa, v. 32, n. 3, p. 567-575, 2008. DOI: http://dx.doi.org/10.1590/S0100-67622008000300017.

SOMOGYI, Z.; CIENCIALA, E.; MAKIPAA, R.; MUUKKONEN, P.; LEHTONEN, A.; WEISS, P. Indirect methods of large-scale forest biomass estimation. European Journal of Forest Research, v. 126, n. 2, p. 197-207, 2006. DOI: https://doi.org/10.1007/s10342-0060125-7. 